ISSN 1119-7455

\title{
ASSESSMENT OF THE ROLE OF COOPERATIVE SOCIETIES IN COCOA PRODUCTION BY SMALLHOLDERS IN OWAN-WEST LOCAL GOVERNMENT AREA OF EDO STATE, NIGERIA.
}

\author{
Omoregbee F.E. and Okoedo-Okojie D.U. \\ Department of Agricultural Economics and Extension Services, Faculty of Agriculture, \\ University of Benin, Benin-City, Nigeria
}

\begin{abstract}
.
Multi-stage and proportional sampling procedure was used to select 102 respondents made up 60 cooperators chosen from 8 registered cooperative societies and 42 non-cooperators in the study area. $A$ well structured interview schedule was used to collect data from the respondents and analyzed using frequency counts, percentages, means and t-test analysis. Results showed that the mean ages of cooperators and non-cooperators were 50 years and 48 years respectively, 53\% of the cooperators and $26 \%$ of non-cooperators have been engaged in cocoa farming between 11 and 25 years and most (82\%cooperators and $71 \%$ non-cooperators) of the respondents had low educational background as they only spent 6 years and 7 years respectively in formal education. The mean output and income of cooperators were $5,716.67 \mathrm{~kg}$ and $\$ 70,116.69$ while the mean for non-cooperators were $7,107.14 \mathrm{~kg}$ and $\$ 78,571.43$. The cooperators and non-cooperators mean farm sizes were 5 hectares and 6 hectares respectively. Generally, the cooperators actively participated in cooperative activities except in seminars in which their participation was low. Cooperative societies in the study area played leading roles in cocoa production as they assisted cooperators in marketing of produce, storage of harvested products, supply of inputs and organizing workshops but negligible influence on cooperators' output and income. Results of hypotheses tested in the study revealed that the farm output and income of non-cooperators were significantly higher than that of cooperators contrary to expectation Recommendation was made that cooperative societies should encourage their members to attend seminars and workshops as a way of building up members' capacity to acquire knowledge and information.
\end{abstract}

Key words: role, cooperative societies, cocoa production, output and smallholders.

\section{INTRODUCTION}

The importance of cocoa in the Nigeria economy cannot be over emphasized. This is because cocoa is an important source of foreign exchange to the Nigerian government and income to many Nigerian farmers. According to International cocoa organization (ICCO)(2006), cocoa is produced in countries within $10^{\mathrm{oN}}$ of the equator where the climate is appropriate for growing trees, largest producing countries being Cote d' Ivoire, Ghana and Indonesia.

In these countries smallholder yields per hectare range from $200 \mathrm{~kg}$ in Ecuador to $1,500 \mathrm{~kg}$ for smallholders in Indonesia, Ghana $300 \mathrm{~kg}$ and cote d'Iviore $450 \mathrm{~kg}$. de lattre-Gasquet et al. (1998) reported that almost $90 \%$ of cocoa production comes from smallholdings under 5 hectares. They further stated that of the 14 million global estimates of workers engaged in cocoa production, 2.5 million of them are smallholders. This excludes those for whom cocoa is not the main activity. Nigeria is one of the cocoa producing countries with about 1.20 million workers involved in cocoa production (ICCO, 2006).

Cocoa production by smallholders in Nigeria and Owan-West local government area (LGA) in particular is faced by many constraints. With the promise of high yields, many smallholders have replaced their native cocoa with a low-quality hybrid that growth in open fields and requires the application of agrochemicals (CBN, 2004). The full-sun cocoa hybrids have led to land degradation and consequently reduced soil fertility.Smallholders may receive a higher yield cultivating lowquality hybrid but the inferior cocoa brings everlower prices and requires costly agrochemicals Rainforest alliance (2006), opined that smallholders have lost their access to overseas markets and a major source of income. As one of 
the effective mcans of overcoming most of these obstacles to sustainable smallholder cocoa production, cooperative cocoa production in which farmers pull their resources together to increase agricultural productivity and enhance the economic and social status of member farmers has been suggested (Nweze, 2003). Interest in cooperative societies has grown widely in the study area (Unuigbe, 2005).At various times; Federal and State governments have endorsed cooperative societies as instrument for socio-economic transformation of rural areas (ECF, 2002). Cooperative societies' increasing involvement in production and farm imputs distribution in Nigeria has been widely reported. These include marketing, processing, supply of farm inputs (seeds, fertilizers, chemicals and modern farm implements),

consumer goods, credit and banking, insurance, warehousing, transportation, farm extension and relevant support such as research and publication (Alüfohai and Ilavbarhe, 2000; FAO, 1993 and Nweze, 2003). The question therefore is whether this has been the case for the cocoa smallholders as members of cooperative societies. Also, what is the socio-economic background of cocoa smallholders? to what extent have cocoa smallholders been involved in cooperative societies?, and what role has cooperative societies played in cocoa production in the study area? To answer these questions, this study was designed to assess the role of cooperative societies in cocoa production in Owan-west LGA. The specific objectives of the study were to:

(1) examine the socio-economic characteristics of cocoa smallholder co-operators and nonco-operators in the study area;

(2) determine cocoa smallholder co-operators extent of participation in cooperative societies .

(3) determine the output and income levels of cocoa smallholder co-operators and nonco-operators

(4) delineate the role of cooperative societies in cocoa production in the study area.
Hypotheses for the Study.

a. There is no significant difference in farm output and income of cocoa smallholder cooperators and non-cooperators in the study area;

b There is no significant difference between the socio-economic characteristics of cocoa smallholder cooperators and non-cooperators

\section{MATERIALS AND METHODS}

The study was conducted in Owan-West LGA. Owan-west LGA is one of the eighteen LGAs in Edo State with administrative headquarters at Sabongida-Ora. It shares boundaries with Owan-East LGA in the north, Ovia North-East and Uhunmwode LGAs in the south, Ondo state in the west and EsanWest LGA in the east. It has a total population of 27,000 people and a total area measuring 102.45 square Kilometers (Owan-West LGA Diary, 2004). Cocoa is the major cash crop produced by farmers in the study area.

A multi-stage sampling procedure was used to select respondents for the study. This was done as follows. The first stage involved getting a list of all registered farmers' cooperative societies aid iarmers that are not members of cooperative socieics in the study area from the ministry of commerce and trade. This gave a total of 8 registered cooperative societies.

\section{Table 1: Sampled Cooperative Societies and Cocoa Smallholders Cooperators' and non cooperators'-}

\begin{tabular}{llll}
\hline Name of Cooperative & $\begin{array}{l}\text { Membership } \\
\text { Strength }\end{array}$ & $\begin{array}{l}\text { Cocoa } \\
\text { Farmers }\end{array}$ & $\begin{array}{l}\text { Respondents } \\
\text { Selected }\end{array}$ \\
\hline Owan Teachers C.T.C.S LTD & 56 & 18 & 9 \\
Uhonmora-Ora C.T.C.S LTD & 45 & 14 & 7 \\
Uhonmora-Nol.M.P.C.S LTD & 37 & 12 & 6 \\
$\begin{array}{l}\text { Sabongidda-Ora } \\
\text { F.M.P.C.SLTD }\end{array}$ & 75 & 25 & 14 \\
Uhonora-Ora F.M.P.C.S LTD & 42 & 13 & 6 \\
Avbiosi F.M.C.S L.d & 40 & 13 & 6 \\
$\begin{array}{l}\text { Sabondida-Ora Community } \\
\text { F.M.P.C.S LDD }\end{array}$ & 44 & 14 & 7 \\
Ivbiosakan C.P.M.S LTD & 35 & 11 & 5 \\
Total & 374 & 120 & 60 \\
Total number of non- & & & 42 \\
cooperators & & & 102 \\
Grand total & & & \\
\hline
\end{tabular}


Table 2: Socio-economic Characteristics of Respondents

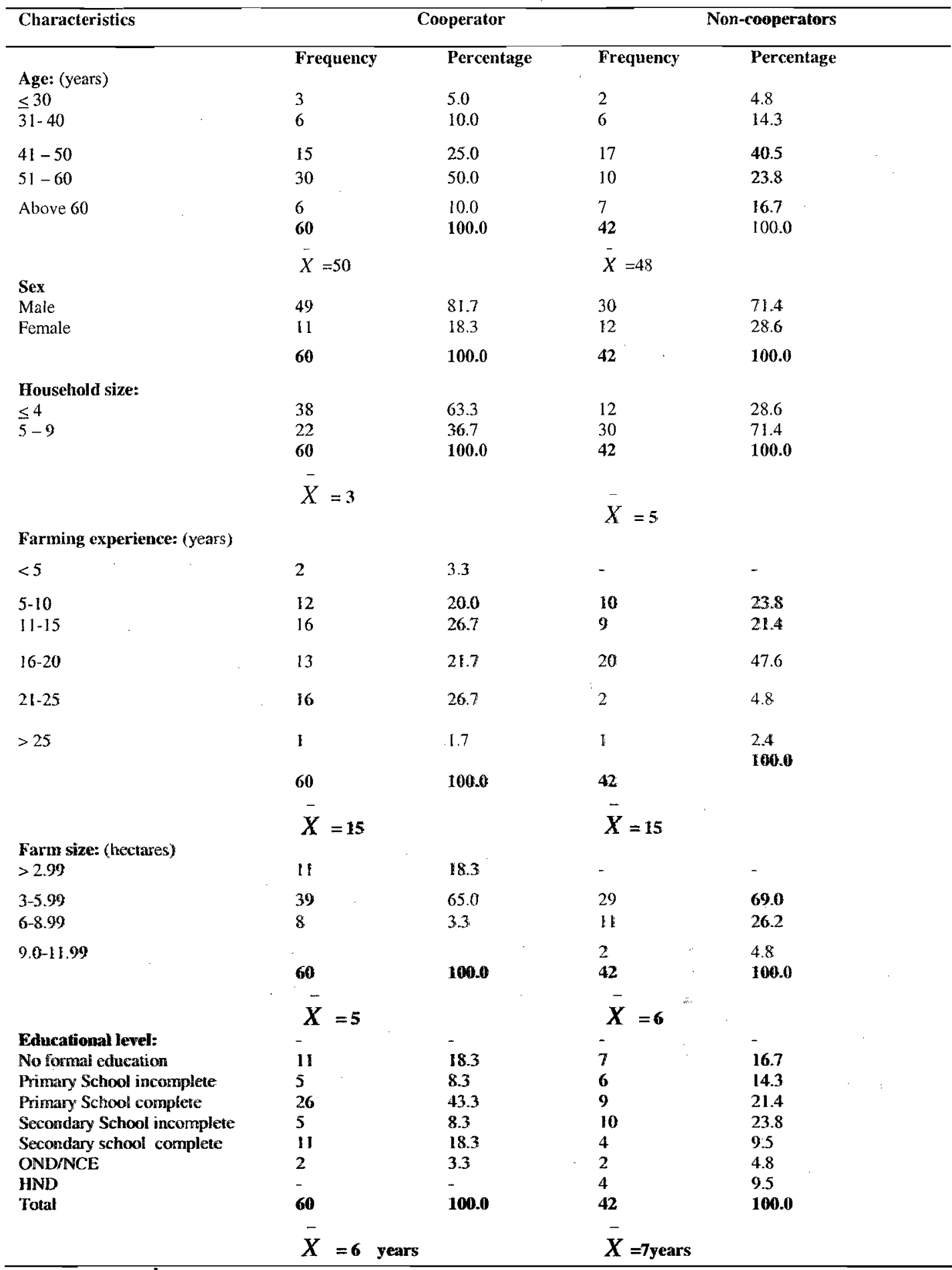

Source: Field survè data, 2005 
At the second stage, a list of all financial members of registered cooperative societies was obtained. This summed up to 374 cooperators (Table 1).This was followed by selection of cooperators who are farmers with cocoa as their major cash crop in the cropping mixture and this gave a total of 120 cocoa smallholders. The final stage involves a simple random and proportional sampling of $50 \%$ of cocoa smallholders. Also, the total number of non-cooperators selected for interview was forty-two (42). This gave a total of 102 "respondents (Table 1).

Primary data were obtained from the respondents through the use of a well structured interview schedule by the researchers and with the assistance of four (4) trained enumerators.

Data obtained were analysed using frequency counts, percentages and means. The ttest was used to test the hypotheses of the study.

Dependent variables of the study were cocoa output and respondents' annual farm income while the independent variable was level of involvement in cooperative activities. Other variables include: age, sex, and educational status, household size, farming experience and farm size. Levels of involvement in cooperative societies was measured as attendance at ordinary general meetings, payment of dues, regularity of annual general meetings and participation in seminars and were measured on a four point scale as follows: Not at all (1), sometimes (2), regular (3) and very regular (4). Role of cooperative societies in cocoa production was measured as activities carried out by the societies. Respondents were asked to rate the activities on a five point scale ranging from not at all(1), poor(2), fair(3), good(4) and very good (5). Similarly, respondents' level of satisfaction with cooperative societies' role in cocoa production was measured on a five point scale which were: undecided (1), not very satisfied (2), not satisfied (3), satisfied (4) and very satisfied (5). Age was measured in years. Sex is a nominal variable and was measured as follows male $=I$ and female $=2$. Education was measured as years spent in formal education. Household size was measured as the number of people who eat from the same cooking pot. Farming experience was measured as the number of years spent in farming. Farm size was measured in hectares and farm output was measured in kilogrames. Annual farm income was measured as amounts realized from sale of cocoa. To capture the combined influence of ilevels of involvement in cooperative societies on cooperators' farm output and income t-test analysis was employed. The explicit form is spocifitied as follows: $t=\frac{\bar{x} \mu}{s / \sqrt{n}}$

Where:

$\bar{X}=$ sample mean

$\underline{\mu}=$ population mean

$\mathrm{s}=$ standard deviation

$V_{n}=$ square root of sample

$\mathrm{n}=$ sample size

\section{RESULTS AND DISCUSSION}

Socio-economic characteristics of the respondents.

Data in Table 2 reveal the distribution of the respondents according to their socio-economic characteristics. Half $(50 \%)$ of the cooperators fall into the age bracket of 51-60 years while about $41 \%$ of non-cooperators are $41-50$ years of age. The average ages of cooperators and noncooperators are 50 years and 48 years respectively. This implies that the cooperators are older than the non-cooperators cocoa smallholders.Most $(82 \%)$ of cooperators and $71 \%$ are male. Most $(81 \%)$ of cooperators had formal education which terminated at the OND/NCE level whereas most $(83 \%)$ noncooperators had formal education which terminated at the HND level. The noncooperators acquired higher level of formal education than the cooperators. The average household size of the cooperators is 3 with majority (63\%) having less than or 4 members in their households while the average household size of the non-cooperators is 5 with majority (71\%) having between 5 and 9 members in their households. The mean farming experience of cooperators and non-cooperators is 15 years with more than half $(53 \%)$ of the cooperators and about $73 \%$ of the non-cooperators have been producing cocoa between 11 and 35 years. The mean farm sizes of cooperators and noncooperators are 5 hectares and 6 hectares respectively but majority $(65 \%)$ of the cooperators farm size is between 3 and 5.99 hectares whereas all (100\%) non-cooperators are between 3 and 11.99 hectares. Findings in Table 2 showed that a higher proportion of the cocoa smallholder cooperators $(X=50)$ are older than cocoa smallholder non-cooperators $(\bar{X}=48)$ but having the same farming experience of at least 15 years. This means that both groups of farmers have a wealth of experience. However, the younger non-cooperators are better placed than the cooperators as a combination of strength and experience will have greater influence on overall farm productivity. Nevertheless, cooperators wealth of experience could be utilized during cooperative societies training programmes as well as constituting a source of information on cocoa farming to new cocoa farmers. Cocoa 
production in the study area is mainly (82\% cooperators and $71 \%$ non-cooperators) done by the male and some (18\% cooperators and $17 \%$ non-cooperators) of the cocoa smallholders have no formal education. This indicates that a good number of the respondents can neither read nor write. The small household size $(\bar{X}=3)$ of majority of the cocoa smallholder cooperators implies that they depend on hired labour to work on their cocoa farm whereas non-cooperator cocoa smallholders depend more likely on family labour as majority $(71 \%)$ of them have between 5 and 9 members in their households.

\section{Cocoa smallholder cooperators' participation in cooperative activities.}

Table 3 shows cocoa smallholder cooperators' level of involvement in cooperative activities. The results show that cooperators' level of involvement is high in payment of dues $\overline{(X}=33.7)$, attendance at ordinary general meetings $\overline{(X}=33.3)$ regularity of annual general meetings $\overline{(\mathrm{X}}=2.50)$ but low participation in seminars $(\bar{X}=1.97)$. Generally, cooperators are more involved in payment of dues and attending ordinary general meetings than annual general meeting and seminars. Cooperatives perform diverse functions such as marketing, processing supply of farm inputs and consumer goods, credit and banking, insurance, ware housing, transportation, farm extension and relevant support such as research and publication(Alufohai and llavbarhe,2000).. Cooperative meetings provide the forum for disseminating information to members on these roles. Cooperative training function is usually actualized through seminars. Low participation of cooperators in seminars organized by their cooperative societies may be attributed to the low educational background of most $(78 \%)$ cooperators in the study area.

Table 3: Cooperators involvement in cooperative activities $(N=60)$

\begin{tabular}{lll}
\hline Level of participation & Mean & Rank \\
\hline Attendance at ordinary & 33.3 & 2 \\
general meetings & & \\
$\begin{array}{l}\text { Payment of dues } \\
\text { Regularity of annual }\end{array}$ & 33.7 & 1 \\
$\begin{array}{l}\text { general meetings } \\
\text { Seminars }\end{array}$ & 2.50 & 3 \\
\hline
\end{tabular}

$\bar{X}>2.50=$ high participation, $\bar{x}<2.50=$ low participation

Source: Field survey data, 2005

Farm output and income of cocoa smallholder cooperators and non-cooperators.

Table 4 shows the farm output and income of cocoa smallholder cooperators and noncooperators. The maximum and minimum output range of cooperators is $9,001-11,000 \mathrm{~kg}(1.7 \%)$ and $3,001-5,000 \mathrm{~kg}(55 \%)$ whereas the maximum and minimum output of non-cooperators is above $11,000 \mathrm{~kg}(2.4 \%)$ and $5,001-7,000 \mathrm{~kg}$ $(40.5 \%)$. The mean outputs of cooperators and non-cooperators are $5,716.67 \mathrm{~kg}$ and $7,107.14 \mathrm{~kg}$, respectively. This indicates that non-cooperators farm output is higher than the cooperators. This is explained by the fact that the cocoa smallholder non-cooperators operated larger farms than the cocoa smallholder cooperators as revealed in Table 2. Similarly, cocoa smallholder non-cooperators earned higher annual farm income than cooperators. As shown in Table 4, the mean farm income of noncooperators is $\$ 78,571.43$ yearly while that of cooperators is $770,116.67$ yearly. The modal annual farm income of cooperators is between $\$ 60,001$ and $\$ 70,000$ whereas the modal annual farm income of non-cooperators is between $\$ 80$, 001 and $\$ 90,000$.

Table 4: Output and income of respondents

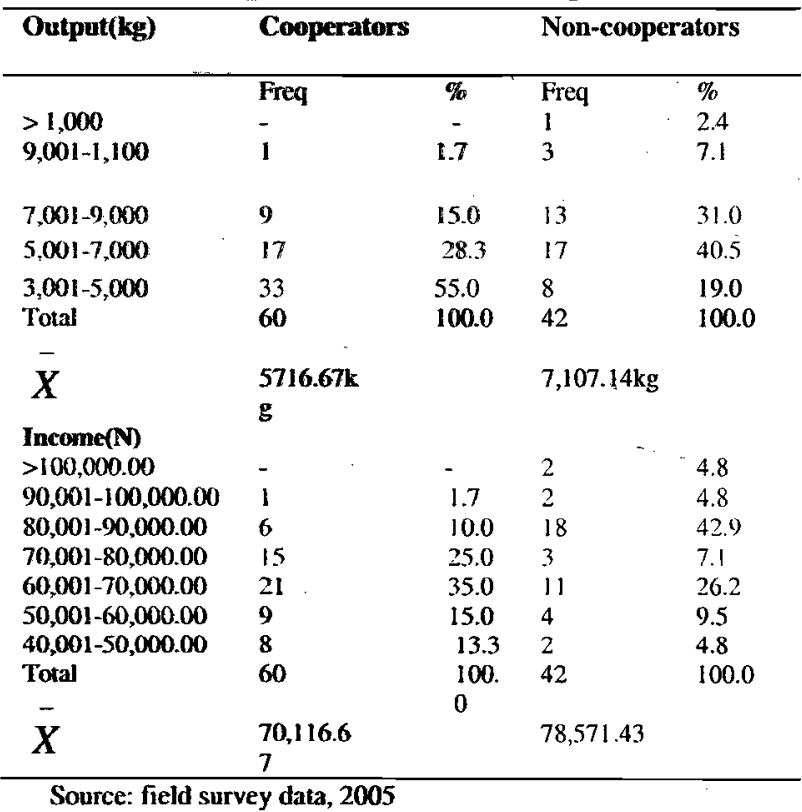

Source: field survey data, 2005

\section{Roles of cooperative societies in cocoa production.}

Cooperative societies performed seven roles in smallholder cocoa production in the study area (Table 5).The most performed role is marketing of produce ( $\bar{X}=4.0$ ), followed by storage of harvested produce $\overline{(X}=3.95)$, supply of chemicals $\overline{(X}=3.93)$, supply of improved varieties $(\bar{X}=3.88)$, credit supply $(\bar{X}=3.65)$, supply of fertilizers $(\overline{\mathrm{X}}=3.55)$ and organizing of workshops $(\bar{X}=2.87)$ being the least performed role. Respondents were asked to indicate their level of satisfaction with the performance of the identified roles of cooperatives in. smallholders' cocoa production especially as it affects their 
farm enterprises. Their responses are as shown in Table 6 .

Table 5: Cooperative Societies Role in Cocoa Production in the Study Area.

\begin{tabular}{lll}
\hline Role & Mean & Rank \\
Marketing of produce & 4.00 & 1 \\
Storage of harvested product & 3.95 & 2 \\
Supply of chemicals & 3.93 & 3 \\
Supply of improved varieties & 3.88 & 4 \\
Credit supply & 3.65 & 5 \\
Supply of fertilizers & 3.55 & 6 \\
Organizing workshops & 2.87 & 7 \\
\hline
\end{tabular}

$1=$ most performed role $7=$ least performed role

Source: Field survey data, 2005

Table 6: Cooperators' Level of Satisfaction With their Cooperative's Role in Cocoa Production.

\begin{tabular}{lcc}
\hline Role & Mean & Remark \\
\hline Credit facilities & 4.18 & Satisfied \\
Marketing of produce & 4.17 & Satisfied \\
Thrift collection & 3.73 & Satisfied \\
Input supply & 4.03 & Satisfied \\
Storage of harvested & 4.15 & Satisfied \\
Produce & & \\
Provision of fund & 3.15 & Satisfied \\
\hline
\end{tabular}

Mean $>3$ = Satisfied; Mean $<3$ not Satisfied.

Source: field survey data, 2005.

Table 6 shows respondents' level of satisfaction with their cooperatives performance of their roles in cocoa production. Respondents' mean values of level of satisfaction reported in descending order are as follows: credit facilities $\overline{(X}=4.18)$, marketing of produce $\overline{(X}=4.17)$, storage of harvested produce ( $\bar{X}=4.15)$, input supply $(\bar{X}=4.03)$, thrift collection $\overline{(X}=3.73)$ and provision of fund $\overline{\mathrm{X}}=3.15)$. Generally, respondents were least satisfied with the performance of providing funds by their respective cooperatives. Funds are required by smallholders to meet production costs. Production costs constraints tend to hinder the farmers from realizing expected output from their farms and consequently lost of income.
Results of t-test analysis showing differences in farm output, income and socio-economic characteristics of cocoa smallholder cooperators and non-cooperators

Data in Table 7 reveal that the difference in output average $(1390.47 \mathrm{~kg})$ between cooperators $(5,716.67 \mathrm{~kg})$ and non-cooperators $(7,107.14 \mathrm{~kg})$ is significant at $1 \%$ level. This implies that the output of non-cooperators is significantly higher than that of cooperators contrary to expectation. Likewise, the difference in average annual income (N8, 454.67) between cooperators (N70, 116.67) and non-cooperators (N78, 571.43) is significant at $1 \%$, indicating a significantly higher annual income of non-cooperators than cooperators. The implication of these findings is that cooperative societies in the study area have negligible influence on cocoa smallholder cooperators' production output and income. This could be due to poor development of cocoa smallholder cooperative societies or the cooperatives are not sufficiently alert to production and marketing opportunities which cooperators could take advantage of. Table 8 shows the significant difference in the socioeconomic status of cooperators and noncooperators. Age, educational level and farming experience of the cooperators and noncooperators are significantly different at $5 \%$ level. Household size and farm size of noncooperators are different from cooperators at the $5 \%$ level. This means that non-cooperators have more access to labour than the cooperators in which case there is a reduction in production cost. The degree of access to labour is associated with farm size. The more labour available, the higher the probability of maintaining bigger farms. The bigger the farm size, the higher the output.

Therefore, cooperative society in the study area did not contribute significantly to cooperators' farm output and income. The role farmers' cooperative societies played in cocoa production in the study area is limited to providing training and support services which individual cooperators operating alone cannot afford. 
Table 7: Test of Difference in Cocoa smallholder Cooperators and non-cooperators' farm output and income

\begin{tabular}{|c|c|c|c|c|c|}
\hline Variables & $\begin{array}{l}\text { Cooperators } \mathrm{N}=60 \\
\bar{X}\end{array}$ & $\begin{array}{l}\text { Non- cooperators } \\
\mathrm{N}=42 \\
\bar{X}\end{array}$ & t-value & $\begin{array}{l}\text { Difference } \\
\vec{X} \cdot \bar{X}\end{array}$ & Remark \\
\hline Output $(\mathrm{kg})$ & $5,716.67$ & $7,107.14$ & 4.254 & 1390.47 & Significant \\
\hline Income $(\mathbb{N})$ & $70,116.67$ & $78,571.43$ & 3.248 & 8454.76 & Significant \\
\hline
\end{tabular}

$\overline{\mathrm{P}}<0.0 \mathrm{i} ; \mathrm{t}_{\mathrm{l}}=2.63$

Table 8: Test of Difference in Cocoa smallholder Cooperators and non-cooperators socio-cconomic characteristics

\begin{tabular}{|c|c|c|c|c|c|}
\hline Variables & $\begin{array}{l}\text { Cooperators } \\
\begin{array}{l}\mathrm{N}=60 \\
\bar{X}\end{array}\end{array}$ & $\begin{array}{l}\text { Mean Non- } \\
\text { cooperators } \\
N=42 \\
- \\
X\end{array}$ & t-value & $\begin{array}{l}\text { Diflerence } \\
\bar{X} \cdot \bar{X}\end{array}$ & Remark \\
\hline Age & 50.00 & 48.33 & 1.67 & 0.798 & NS \\
\hline Education & 6.27 & 7.19 & 0.92 & 0.991 & NS \\
\hline Farming experience & 16.67 & 15.02 & 0.64 & 0.584 & NS \\
\hline $\begin{array}{l}\text { Household } \\
\text { Size }\end{array}$ & 3.83 & 5.57 & -1.74 & 3.682 & $s$ \\
\hline Farm size & 5.05 & 6.07 & -1.02 & 2.731 & $S$ \\
\hline
\end{tabular}

\section{CONCLUSION}

The mean ages of the cooperators and non-cooperators were 50 years and 48 years and both groups of respondents have been cocoa farmers on the average of 15years. The respondents were mainly smallholders with majority of cooperators and non-cooperators maintaining farm size of 5 hectares and 6 hectares respectively. The mean output and income of cooperators were $5,716.67 \mathrm{~kg}$ and $\$ 70,116.69$ while the mean for non-cooperators were $7,107.14 \mathrm{~kg}$ and $\$ 78,571.43$. Most of the respondents ( $82 \%$ cooperators and $71 \%$ noncooperators) had low educational background as they only spent 6 years and 7 years respectively in formal education. Most of the cooperators maintained a small household size of 3 members whereas the non-cooperators' household size ranged from 5 to 9 members. Cooperators actively participated in cooperative activities except in seminars in which their participation was very low. The most performed role by cooperatives in cocoa production was marketing of produce while the least performed role was organizing workshops for members. Cooperators were generally satisfied with their cooperatives role in cocoa production but were least satisfied with their role as providers of funds. Results of hypotheses tested in the study revcaled that the farm output and income of non-cooperators were significantly higher than that of cooperators contrary to expectation. The role of farmers' cooperative societies in the study area is limited to providing training and support services to cooperators.

\section{Recommendations}

Based on findings and conclusions reached in this study, the following recommendations are made:

(1) Most farmers' opportunity to acquire education is when they come in contact with extension workers or attend seminar/training workshops organized by the group in which they are affiliated. Cooperative societies should encourage their members to take advantage of their membership of cooperatives by organizing seminars and literacy training workshops for their members at regular intervals. Also, efforts should be made to encourage non-cooperators to affiliate with cooperative societies so as to benefit from these services offered by cooperatives.

(2) Cocoa being a cash crop requires sufficient funds to produce for export. Cooperators in the study area were generally less satisfied with cooperative society's role as providers of fund. Sole 
dependence on membership dues and thrift collection cannot meet the fund requirements of members. Therefore, the Cooperatives societies should be more alert to other sources of funds such as grants from local, national and international bodies as well as engaging in fund raising activities. This done, cooperative society will be better placed to raise their lending portfolio. This can help cocoa farmers to meet this need for funds by beefing up its lending portfolio;

(3) The roles performed by Cooperative societies as indicated by study's findings portray the cooperative society as a service delivery organization and not just the provision of loans per se. Therefore, products of the cooperative society should be demand driven and product development should depend on the constraints faced by the cocoa smallholders.

(4) T-test analysis results reveal a significantly higher output and income of noncooperators than that of cooperators. The analysis further indicated a significant difference in farm size and household size of non-cooperators and cooperators. To enhance cooperators' output and consequently income, cooperative societies should encourage cooperators to adopt labour saving technologies on their farms.

\section{REFERENCES}

Alufohai G.O. and Ilavbarhe, K.O. (2000)."Women cooperative societies and access to productive resources in three local government areas of Edo State, Nigeria" Journal of Agriculture, Forestry \& Fisheries.Vols. 1\&2:. 46-50.

Central Bank of Nigeria (CBN, 2004).Annual Report and Statement of Accounts. For the year ended 31 ${ }^{\text {sl }}$ December. p. 24.

De Lattre-Gasquet, M., D. Despreaux, M. Barrel (1998). Prospective Study of the cocoa commodity channel. Recherché Development, 5(6): 423-434.
Edo Cooperative Federation Limited (2002).Cooperative Development

$\therefore \quad$ Policy for Nigeria. of Edo Cooperative Federation Bye-Laws. P.4

International Cocoa Organization (ICCO, 2006)"How many smallholders are there worldwide producing Cocoa? What proportion of cocoa worldwide is produced by smallholders?

Nweze, N.J, (2003)."Cooperative promotion in rural communities: The project approach" Nigeria Joumal of Cooperatives 2.(2): 76- 89.

Owan-West Local Government Council (2004). Diary p. 10.

Rainforest Alliance (2006) Sustainable Agriculture Programme .

Unuigbe, O.M. (2005) Effects of cooperative societies on cocoa production in OwanWest local government area of Edo state, Nigeria. Unpublished B.Sc thesis report. Department of Agricultural Economics and extension services, University of Benin, Benin-City, Nigeria. 